\title{
Socioeconomic Analysis of Rice Farmers and Effects of Group Formation on Rice Production in Ekiti and Ogun States of South-West Nigeria
}

\author{
C. A. Afolami, A. E. Obayelu, M. U. Agbonlahor \& O.A Lawal-Adebowale \\ Department of Agricultural Economics and Farm Management, UNAAB Abeokuta \\ E-mail: carolynafolami@yaoo.co.uk; obayelu@yahoo.com
}

Received: May 10, $2011 \quad$ Accepted: June 9, $2011 \quad$ Online Published: February 2, 2012
doi:10.5539/jas.v4n4p233
URL: http://dx.doi.org/10.5539/jas.v4n4p233

\begin{abstract}
The study was conducted to determine the impact of farmers' membership of cooperative societies on rice production. Against the backdrop that the promotion of membership of cooperative society among farmers would give them better access to agricultural inputs and consequently improve their income. Multistage sampling technique was employed to select a total of 310 rice farmers. Data collected were analyzed using descriptive statistics, budgetary technique and inferential statistics. The results revealed the mean age of the rice farmers as 48 years. Majority $(92 \%)$ of the farmers produced upland rice, with a single harvest per year using mainly owned resources. Family labour was the most important source of farm labour in rice cultivation and about $60 \%$ of the members of the farm families participated in the family rice farm. The results further showed that $38.9 \%$ of rice farmers had primary education, $27.4 \%$ had secondary education, while $25.1 \%$ had no education. A total of $71 \%$ of the rice farmers were members of rice farmers' cooperative societies, while $29 \%$ were not. The average farm size cultivated was $1.72 \mathrm{ha}$ and 1.64 ha for cooperative and non-cooperative members respectively. The result also showed that there is no significant difference in the gross margin per hectare realized by farmers that were cooperative members $(90,222)$ and the non cooperative members $(\$ 92,986)$. The input-use structure showed that cooperative members were more intensive users of purchased inputs like fertilizer and pesticides valued at $\$ 124,555$ per ha (about $41 \%$ of variable cost) compared to the non cooperative members valued at $\$ 57,647$ per ha (about $22 \%$ of the variable cost). Almost all the groups were established to serve as receptacles for subsidized agricultural services and inputs rather than real producer organizations that seek to attract commercial providers of services and ensure efficient marketing of their farm outputs. Further revelation from the study is the fact that membership of cooperative society was found to be influenced by household size, access to extension services, number of rice farms owned, access of rice farmers to herbicide and quantity of rice output. The non-significant difference in the gross margin of cooperative and non-cooperative members despite the greater intensity of use of purchased inputs (fertilizer and pesticide) by cooperative members suggests the need for monitoring of rice farmers who are cooperators in order to ensure that the substantial inputs are rightly channeled.
\end{abstract}

Keywords: Group formation, Rice production, Cooperative, Ogun and Ekiti State

\section{Introduction}

The agricultural production landscape in Nigeria is dominated by small-scale, resource-poor farmers, who produce over $90 \%$ of the food consumed in the country in small $(<2$ ha) dispersed holdings. Farm production and resources' productivity in the farms are limited by lack of access to agricultural inputs. Improving smallholder farmers' access to agricultural services is therefore a central challenge facing governments in sub-Saharan Africa (Stringfellow, et al 1997). Group farming was introduced as the first attempt to organize farmers' production cooperative in order to solve problems of small farmers after the $2^{\text {nd }}$ world war in many developing countries (Sherief, 1991). Cooperative plays a vital role in many aspects of human interaction, including income generation, risk reduction, social networking, education, information sharing and public service provision. By pooling capital, labour, goodwill and other resources, members are able to carry out profitable activities, which, if undertaken by individuals, would involve greater transaction cost, risk and efforts. It therefore, implies commonality in purpose, objectives, and means of how to achieve them (Ukaga, 1992; USDA, 2006; Grazhdaninova, and Lerman, 2005). The aim of group farming is to use more efficiently the scarce resources of 
land, labour, skills and capital. The aim of groups formation and the promotion of inter-group collaboration are to broaden the local economies-of-scale, strengthen the market and bargaining power of the farmers, enhance their access to support services and to encourage community participation and cooperation. Farmers' cooperation, especially among those having commercial potential, is widely perceived as one mechanism of improving their access to agricultural services. By working together, farmers can realize the scale economies of bulk acquisition and enter into more stable trade agreement with suppliers or processors. Research has shown that the incentive to form group is enhanced when members believe in the combined efforts and goodwill of one another to raise their standard of living i.e; groups are formed when there is a likelihood of synergistic outcome from pooled efforts in the pursuit of a collective goal. There are broad and diverse ranges of activities conducted within and by organized groups of individuals, including political, economic and social activities. In the long run, the groups may attract additional funds and support, since outside agencies are eager to work in areas where rural people are well-organized. In recent years, this view has influenced the design of many programmes of assistance to smallholders in Nigeria to the extent that donors and Non Governmental Organisations have often made group formation a prerequisite for accessing project resources. Additionally, from the donors' perspective, there are significant advantages in using groups as recipients of interventions rather than individuals, as costs are lower, better means of monitoring impact are provided and resources can be disbursed more rapidly.

Specifically, this study analysed the socioeconomic characteristics of rice farmers; examined the nature and degree of group formation among rice farmers in the study areas, determined the effect of group formation and other factors on rice production in the study area and described the obstacles militating against group formation by rice farmers.

\section{Theoretical Framework and Literature Review}

Groups are fundamental to economic, social and political outcomes, despite their relative neglect by economists, who continue to treat groups as quasi-individuals (Rosemary, et al., 2003). A group can be defined as several individuals who come together to accomplish a particular task or goal. It is a collection of people, (minimum of five) who come together on a free and voluntary basis, and with a spirit of co-operation to work together for social and economic benefit of all. Although group can be gender specific in membership or gender bias in activities, it can also be for specific economic membership. Also, the focus can be on credit rotation and sourcing, or an informal development group in a community. Membership of groups is frequently a means to reinforce or construct identity. The capacity of groups to reinforce identity, a sense of self and relationships to society, in itself provides an incentive for cooperative behaviour and empowering action in the interests of the group. However, individuals may co-operate in groups without expecting a return. They may take such action through a sense of social responsibility, a sense of duty, or commitment, or because they enjoy the activity itself (Alkire and Deneulin 2002).

There are several theories as to why groups develop. A classic theory, developed by Homans (1950), suggests that groups develop based on activities, interactions, and sentiments. Basically, the theory posits that when individuals share common activities, they will have more interaction and will develop attitudes (positive or negative) toward each other. The major element in this theory is the interaction of the individuals involved. Group formation plays a critical role in collaborative learning (CL), enhancing the development of democratic ideas and promotes brotherhood economics. The strength of a group is therefore a function of the individuals in the group, the interactions of the group members and the influence of the group on the community.

Tuckman and Jensen (1977) draw on the movement known as group dynamics, which is concerned with why groups behave in particular ways. This offers various suggestions for how groups are formed and how they develop over time. The formation of some groups can be represented as a spiral; other groups form with sudden movements forward and then have periods with no change. Whatever variant of formation each group exhibits, they suggest that all groups pass through six sequential stages of development. These stages may be longer or shorter for each group, or for individual members of the group, but all groups will need to experience them. They are forming, storming, norming, performing, mourning and adjourning. One common way to classify group is to identify whether they are formal or informal in nature. Formal work groups are established by an organization to achieve organizational goals. Formal groups may take the form of command groups, task groups, and functional groups.

People want to come together as a group because in a group, members have access to goods and services more easily than they would have on an individual basis (political influence and reduction of transaction costs); members pull together scarce resources, own and manage them themselves in order to overcome poverty, deprivation, powerlessness of an individual person against market forces, unemployment and low self esteem. 
Groups can be learning laboratories for promoting skills such as enterprise management and problem solving; groups are useful receiving mechanisms for resources from Government and development agencies. Group allows more people to be reached; it reduces default through collective risk taking and provides a channel for information and mass education.

Babatunde et al., (2007) observed that, farmers' cooperatives have been in existence in Nigeria for centuries and their importance in pooling resources and contributing to the agricultural development of the country are well documented. Nweke (1979), noted that various problems of Nigerian small farmers like land, labour and capital problems can be solved through cooperatives efforts. Adeyemo (1994), reported that members of cooperative societies performed better in terms of the gross returns to production efforts than individual farmers who are non-members.

\section{Methodology}

Ogun and Ekiti States in southwest Nigeria were selected because of their relative importance in the rice production landscape in Nigeria. Data used for this study came mainly from primary source. A multi-stage sampling procedure was used in the selection of respondents. The first stage was the purposive selection of Ogun and Ekiti states. The second stage was the purposive selection of two (2) delineated Agricultural Development Programme (ADP) zones/blocks from the states with high concentration of rice producers. The final stage was the random selection of 310 rice farmers from the two states proportionate to size.

The data collected were analyzed using descriptive, budgetary techniques and inferential statistics in line with the study objectives. Frequency tables, cross tabulation and percentages were used to describe and summarize the socio-economic characteristics of rice farmers while the budgetary analysis was used to determine the profitability of rice production by both cooperative and non-cooperative members. The Probit regression analysis was used to determine factors that influence farmers' membership of a rice production group. The model is stated as:

$$
M_{i}=\lambda_{k}+\eta_{i} \sum_{i=1}^{n} Z_{i}+v_{i}
$$

The dependent variable $M_{i}$ is 1 if the rice farmer belongs to rice production group and 0 if otherwise $\lambda_{k}, \quad \eta_{i}$ are parameters estimated. $Z_{\mathrm{i}}$, is the matrix for the observations on independent variables considered. Vi is the error term that is assumed to be normally distributed with constant variance and zero mean. The independent variables considered are:

$\mathrm{X}_{1}=$ State dummy (Ekiti State $=1,0$ otherwise $) ; \mathrm{X}_{2}=$ Gender dummy $($ male $=1$, female $=0)$

$\mathrm{X}_{3}=$ marital status (married $=1$ otherwise 0 ); $\mathrm{X}_{4}=$ age of respondent (years)

$\mathrm{X}_{5}=$ Educational qualification (educated $=1$, otherwise 0 ); $\mathrm{X}_{6}=$ household size, (number)

$\mathrm{X}_{7}=$ Number of family member involved in rice production (number); $\mathrm{X}_{8}=$ General farming experience $(\mathrm{yr}) ; \mathrm{X}_{9}=$ Rice farming experience (yr); $\mathrm{X}_{10}=$ Number of farm locations (number)

$\mathrm{X}_{11}=$ Area of rice farm cultivated (ha); $\mathrm{X}_{12}=$ access to fertilizer (yes $=1,0$ otherwise)

$\mathrm{X}_{13}=$ access to herbicides (yes $=1,0$ otherwise); $\mathrm{X}_{14}=$ access to credit (yes $=1,0$ otherwise),

$\mathrm{X}_{15}=$ access to extension services (yes $=1,0$ otherwise); $\mathrm{X}_{16}=$ quantity of rice produced $(\mathrm{Kg} / \mathrm{year})$

\section{Results and Discussions}

\subsection{Rice Production in Ogun and Ekiti States}

Three main varieties of rice are generally cultivated in these states. These are Ofada white, Ofada brown/red, and NERICA. Ofada is a generic name used to describe all local variety of rice produced and processed in the rice producing clusters of South-West Nigeria. The short, robust rice grain (Ofada), believed to be OS6 and ITA 150 varieties, has attained a premium and prominence in Nigeria. It is sold as prepared ready to eat food in most eateries and bukaterias all over Nigeria. It is sold in the raw form packed in 500g pouches by marketers in major cities in Nigeria. The variety is commercially popular due to its nutritional value and the premium price it attracts. The aromatic flavor of the unpolished grains is an additional appealing quality to consumers. The Ministries of Agriculture in Ogun, Lagos and Ekiti States are facilitating systemic change in rice production in a way that benefits the farmers and see ofada rice as a niche market product that could provide opportunity for agricultural growth and development (Dauda, 2009). New Rice for Africa (NERICA) has the potential to thrive well in acidic soils and it is resistance to insect pests and diseases. Nigeria is one of the seven African nations 
including Mali, Gambia, Guinea, Ghana, Sierra-Leone and Republic of Benin where the NERICA rice project is on-going. Within Nigeria, six states including Ogun, Ondo, Taraba, Ekiti, Kaduna and Nassarawa are the current beneficiaries of the project. The initiative is meant to contribute to food security and poverty reduction among African farmers and targets support for small-scale rice producers to improve production.

\subsection{Socioeconomic Characteristics of Rice Farmers in Ekiti and Ogun States}

Table 1 shows that the majority of respondents in Ekiti (94.2\%) and Ogun states (97.6\%) were married. The results of the t-test also confirmed that there is a significant difference (at 10\% probability level) between the mean age of respondents in the two states. While the mean age of respondents in Ekiti was 46.8 years, that of Ogun State was 48.7 years. This implies that rice farmers in Ogun State were older than their counterparts in Ekiti State. Majority of the producers in Ekiti (90.3\%) and Ogun (85\%) States were male suggesting a high dominance of male farmers in rice production. Rice farming is to a large extent a cash crop, and it is usually not a component of household' food crops. The mean household size was approximately 7 in Ekiti and Ogun respectively. About $86 \%$ of the farmers in Ekiti State had access to formal education while in Ogun about $69 \%$ had access to formal education. Table 2 shows that, the average years of farming experience was 18.7 years in Ekiti State compared to 24.5 years in Ogun State; this buttresses the older rice farm families in Ogun State. On farming experience, Ogun State rice producers appear to be more experienced (15.61years) in rice production than their Ekiti (13.63years) counterparts. With respect to the involvement of family members in rice production, it is evident that farmers in both states extensively use family members in production (farm labour). Farmers in Ekiti cultivated an average of 1.99ha while those in Ogun cultivated 1.59ha (Table 3 ). Thus, the relatively younger farmers in Ekiti had larger rice farm sizes than their counterparts in Ogun. Further, Table 3 reveals that $35.9 \%$ of the respondents in Ekiti had access to credit, while only $11.1 \%$ the respondents in Ogun had access to credit. This suggests intensified efforts to encourage rice production in Ekiti through the provision of credit facilities to the young farmers which may be correlated to their higher level of access to formal education. However, the proportion of the respondents with extension contact in Ogun (17.9\%) was higher than that of Ekiti (7.8\%). The wide gap might be related to longer years of existence of Ogun State which makes her farmers to have benefited more from the Agricultural Development Program system.

\subsection{Nature and Degree of Group Formation among Rice Farmers}

Table 3 shows that $77.7 \%$ and $68.1 \%$ of the respondents were involved in cooperative groups in Ekiti and Ogun States respectively. However, further analysis showed that rice farmers' groups in both states were still very weak. The method and impetus for their formation led to their weakness. Majority of the groups were formed to harness the benefit of subsidized agricultural services and inputs rather than being real producer' organizations that would seek out commercial providers of services and products for their members.

\subsection{Group Activities that Encourage Participation}

The problem of poor patronage of cooperative groups and activities has been linked to the absence of relevant projects of social and economic interest to members. The cardinal objective of the network will collapse if members do not actively participate in the projects. To ensure full participation it was therefore necessary to investigate projects of interest that will encourage participation by the rice farmers in the area. Also, the analysis of the activities that will encourage members to participate actively is expected to beam the light on the needs of the members that can best be met through cooperative action. Table 4 shows that a higher proportion of the rice farmers will participate in cooperative projects that will help to access better markets (84\%), credit (72\%), farm inputs $(67 \%)$ and processing mills $(61 \%)$. Access to extension service and tractor services were not considered as major rice production constraints in the states. The result also indicates areas of need for which specific group-based interventions can be targeted to increase rice production and resource productivity. The need for a functional and a proactive rice producers' group is predicated on the need to take full advantages of the huge business opportunity that exist in the Nigerian rice sector; especially in the wake of the intended policy that will prohibit rice import.

\subsection{Costs and Return Structure of Cooperative and Non-Cooperative Members for Rice Production}

Contrary to expectation and in disagreement with the findings of Adeyemo (1994), the cost and return structure of respondents as shown in Table 5 revealed that non-cooperative farmers make more profit $(\mathbb{N} 92,986)$ per hectare of rice cultivated than their cooperator counterparts( $\$ 90,222)$. The lack of significant difference from zero between the gross margin of cooperators and non-cooperative members (despite the better access to purchased inputs fertilizer and pesticide by cooperative members) also suggests that the farmers may be trading in the acquired inputs rather than using them for rice production. In addition, poor farm management practices and sub-optimal use of the inputs may also explain the non-significant difference between the gross margins. The lower gross 
profits of the cooperators suggest the poor performance of the cooperative groups as an economic facilitator for members.

\subsection{Effects of Group Formation on Rice Production in Ekiti and Ogun States}

Factors that influence group membership were identified using the probit regression model. Results revealed that at 5\% significant level, household size and access to extension services have negative influence on rice group membership. At $1 \%$ significant level, access of rice farmers to herbicide negatively influence group membership, while number of farms had positive and significant influence on rice group membership (Table 6). Disaggregated by state, it was found that gender and access to herbicides had positive and significant effect on group membership in Ekiti State (Table 7). In Ogun State, at 5\% level of significant, gender and household size negatively influence group membership while family members in rice farming, number of farm plots, access to herbicide, access to credit facility and rice output had positive influence on rice group membership. Though there is no significant difference in the yield of an average group member and non-member (Table 9), the marginal effects reveal that a unit increase in rice output will increase the probability of group membership by 0.00848 units in Ogun where the parameter of the quantity of rice produced is significantly different from zero (Table 8 ). This might probably be as a result of the ability of the group to influence farm input at a subsidized price to their members.

4.7 Test of Significant Differences in Rice Production Variables between Cooperatives and Non Cooperative Members

Table 9 shows the result of the t-test of mean differences between selected variables of rice farmers that are members of cooperative societies and those that were not. Four production variables namely total hectarage cultivated, number of rice harvest per year, total yield in tonnes/ha and gross margin in naira were tested to ascertain whether there are significant differences between the members and non-members of cooperative societies. The results revealed that there is no significant difference between members and non-members in any of the variables. The implication of this is that group membership does not significantly influence gross margin of rice in the study area. This corroborates the submission that the cooperative groups do not operate by the tenets of modern production cooperatives.

\subsection{Factors Influencing Rice Group Formation and Development in the Study Areas}

The success or failure of a group depends on the extent to which members of the group derive the expected benefits from activities of the group. When the expectations of the group members are readily met, it is certain that they will all be committed to ensuring sustainability of the group through effective participation. In view of this, examination of the factors contributing to the success of the groups showed that access to credit from group facilitation, regular meeting attendance and types of activities engaged in were the most important determinants of groups' success in the states. This implies that members of social group ensure continued existence as long as it affords them the opportunity to obtain financial credit with which they can meet their needs. Membership acquisition of the available loan was also contingent on their regular meeting attendance. Other factors indicated include good leadership by the executives of the group and cooperation among members in working towards achieving the group goals. A higher percentage of the respondents in Ekiti State (68.9\%) and in Ogun State (53.6\%) indicated inability to access credit for investments as a major factor militating against functional group membership (Table 10). The poor financial strength of the groups was also harped as a major constraint to group activities and development. The extent of financial contributions of members therefore has an overriding effect on sustainability of the group.

\section{Conclusions and Recommendations}

The study concludes that while there are obvious economic and social benefits that can be gained by participating in group action, there is however the need for the groups to be proactive and responsive to members' peculiar production and marketing (economic) problems. Majority of the groups that presently exist as production cooperatives, are associations formed or arranged to take advantage of external funding or input supply opportunities. This is accentuated by the fact that none of the groups had any viable committee that seeks to improve the production or marketing economies of the members through outreach to inputs or products markets. The implication is that, the cooperative groups are not self-serving and forward-reaching business units. This outlook poses a serious challenge of sustainability and ability of the groups to survive in the absence of external supports. This was also evident from the fact that membership of rice cooperative group had no significant effect on output of farmers in the pooled results. The study therefore recommends:

- The need to build capacities of members and officials of the groups on the tenets of modern cooperatives as a business and advocacy unit of producers through re-education programme. Such 
programme should be aimed at strengthening the capacities of the groups to be proactive and inward looking in promoting brotherhood economics. Multi-purpose cooperative groups should be encouraged so as to provide the requisite prop needed to sponsor self generated projects without losing focus of rice production and marketing activities. The groups should be encouraged to diversify into other income earning activities. Government agencies and NGOs involved in input and financial intermediations for rice farmers should continue to patronize farmers in groups, while newer ones should be encouraged.

- The need for the restructuring of farmer's cooperative group in such a form that will enhance productivity. Proper monitoring of cooperative group activities by members themselves is also important to ensure that subsidized inputs are actually put into production by members.

\section{Acknowledgement}

The authors gratefully acknowledge the funding support provided by Institute of Food Security, Environmental Resources and Agricultural Research (IFSERAR), Federal University of Agriculture Abeokuta, Ogun State, Nigeria

\section{References}

Babatunde, R.O, Fakayode, S.B, Olorunsanya, E.O \& Gentry, R.A. (2007). Socio-Economics and Saving Patterns of Cooperative Farmers in South-Western Nigeria. The Social Sciences, 2(3), 287-292. Published by Medwell Academic Publishers, Pakistan. [Online] Available: www.medwelljournals.com

Alkire, S. \& S. Deneulin. (2002). Individual motivation, its nature, determinants and consequences within-group behaviour. Group Behaviour and Development: is the market destroying cooperation? J. Heyer, F. Stewart and R. Thorp. Oxford, Oxford University Press.

Adeyemo, R. (1994). A Comparative Study of Cooperative and Non-Cooperative Farmers in the Use of Resources in Nigeria. Journal of Rural Development and Administration, XXVI (1), 52-62.

Dada, O. (2009). Farmers boost ofada rice production. "The Nation", Nigeria newspaper. Published 18/09/2009. [Online] Available: http://thenationonlineng.net/web2/articles/18798/1/Farmers-boost-ofada-rice-production/Page1.html

Grazhdaninova, M. \& Lerman, Z. (2005). Allocative and technical efficiency of corporate farms in Russia. Comparative Economic Studies, 47(1), 200-213. http://dx.doi.org/10.1057/palgrave.ces.8100089

Homans G. C. (1950). The human group. New York: Harcourt, World, and Brace, Inc. In R. Hirokawa, R. Cathcart, L. Samovar, \& L. Henman (Eds.), Small group communication, theory and practice (an anthology), $8^{\text {th }}$ edition (p. 2). Los Angeles: Roxbury Publ Co.

Nkanga, O. M. (1992). Farmers Cooperatives in Nigeria. A vehicle for mutual help and education. A paper presented at the $8^{\text {th }}$ African Educational Research symposium Ohio, University Athens, Ohio. December 5-7, 1992

Nweke, F.I. (1979). Traditional Cooperatives in the Management of Farmland, Labour and Capital in the Small-scaled Cropping System of South-Eastern Nigeria. Paper Presented at the National Conference on Appropriate Strategy for Cooperative Development plan of Nigeria, Nsukka, September 11-14, 1979.

Rosemary T., Stewart, F. \& A. Heyer. (2003). When and How Far is Group Formation a Route out of Chronic Poverty?" A paper presented at the conference 'Staying Poor: Chronic Poverty and Development Policy' to be held at the University of Manchester, 7 to 9 April 2003.

Sherief, A. K. (1991). Kerala, India: Group Farming. Report in Agricultural Extension and Rural Development Department (AERDD) University of Reading, UK: Bulletin 32, 14-17.

Stringfellow, R., Coulter J., Lucey T., McKone C. \& A. Hussain. (1997). Improving the Access of Smallholders to Agricultural Services in Sub-Saharan Africa: Farmer Cooperation and the Role of the Donor Community. Natural Resource Perspectives 20. Overseas Development Institute (ODI): London, June 1997.

Tuckman, B.W. \& Jensen M.A.C. (1977). Stages of Small Group Development Revisited. Group Organization Management, 2, 419 - 427. http://dx.doi.org/10.1177/105960117700200404

United States Department of Agriculture. (2006). Farmer Cooperative Statistics. Service Report 67.

\section{Note}

Note 1 . Access was operationalized as the ability of the farmer to acquire the right quantity, as at when needed, of the specific inputs/services 
Table 1. Respondents Distribution by marital status, age, gender household size and educational status

\begin{tabular}{|c|c|c|c|}
\hline Characteristics & Ekiti State & Ogun State & Pooled \\
\hline & \multicolumn{2}{|l|}{ Marital Status } & \\
\hline Married & $97(94.2)$ & $202(97.6)$ & $299(96.5)$ \\
\hline Single & $6(5.8)$ & $5(2.4)$ & $11(3.5)$ \\
\hline Total & $103(100)$ & $207(100)$ & $310(100)$ \\
\hline \multirow[t]{2}{*}{ Mode } & married & Married & Married \\
\hline & \multicolumn{2}{|l|}{ Age (yr) } & \\
\hline$\leq 30$ & $03(3.9)$ & $04(1.9)$ & $07(2.3)$ \\
\hline $31-40$ & $23(22.5)$ & $33(15.9)$ & $56(18.1)$ \\
\hline $41-50$ & $49(47.6)$ & $94(45.4)$ & $143(46.1)$ \\
\hline $51-60$ & $23(22.3)$ & $56(27.1)$ & $79(25.5)$ \\
\hline $61-70$ & $05(4.9)$ & $16(7.7)$ & $23(7.5)$ \\
\hline$>70$ & $00(0.0)$ & $04(1.9)$ & $04(1.3)$ \\
\hline Total & $103(100)$ & $207(100)$ & $310(100)$ \\
\hline Mean age & 46.75 & 48.72 & 48.07 \\
\hline \multirow[t]{2}{*}{ t-value across the states } & $-94.73^{*}(8.87)$ & & \\
\hline & \multicolumn{2}{|l|}{ Gender } & \\
\hline Male & $93(90.3)$ & $176(85.0)$ & $269(86.8)$ \\
\hline Female & $10(9.7)$ & $31(15.0)$ & $41(13.2)$ \\
\hline Total & $103(100)$ & $207(100)$ & $310(100)$ \\
\hline \multirow[t]{2}{*}{ Mode } & male & Male & Male \\
\hline & \multicolumn{2}{|l|}{ Household Size } & \\
\hline$\leq 3$ & $44(42.7)$ & $121(58.5)$ & $165(53.2)$ \\
\hline $4-7$ & $39(37.9)$ & $69(33.3)$ & $108(34.8)$ \\
\hline $8-11$ & $18(17.5)$ & $12(5.80$ & $30(9.7)$ \\
\hline$>11$ & $2(1.9)$ & $5(2.4)$ & $7(2.3)$ \\
\hline Total & $103(100)$ & $207(100)$ & $310(100)$ \\
\hline Mean HHsz & 6.52 & 6.91 & 6.78 \\
\hline Mode & 5 & 6 & 6.0 \\
\hline Std.deviation & 2.70 & 2.69 & 2.70 \\
\hline \multirow[t]{2}{*}{ t-value } & $-41.00^{*}(2.77)$ & & \\
\hline & \multicolumn{2}{|l|}{ Educational level } & \\
\hline No education & $14(13.6)$ & $64(30.9)$ & $78(25.2)$ \\
\hline Koranic & $0.0(0.0)$ & $8(3.9)$ & $8(2.6)$ \\
\hline Adult literacy & $1(1.0)$ & $4(1.9)$ & $5(1.6)$ \\
\hline Primary education & $33(32.0)$ & $88(42.5)$ & $121(39.0)$ \\
\hline Secondary education & $47(45.6)$ & $38(18.4)$ & $85(27.4)$ \\
\hline Tertiary education & $8(7.8)$ & $5(2.4)$ & $13(4.2)$ \\
\hline Total & $103(100)$ & $207(100)$ & $310(100)$ \\
\hline Mode & Primary education & Primary education & Primary education \\
\hline
\end{tabular}

Figures in parentheses are in percentages except t-value, ${ }^{*}$ significant levels at $10 \%$

Source: Estimates from field survey, 2010 
Table 2. Respondents Distribution by Farming Experience and Involvement of family members in rice production

\begin{tabular}{|c|c|c|c|}
\hline Characteristics & Ekiti State & Ogun State & Pooled \\
\hline & \multicolumn{2}{|c|}{ General Farming Experience (yr) } & \\
\hline$\leq 3$ & $3(2.9)$ & $2(1.0)$ & $5(1.6)$ \\
\hline $4-7$ & $9(8.7)$ & $6(2.9)$ & $15(4.8)$ \\
\hline $8-11$ & $19(18.5)$ & $12(5.8)$ & $14(4.5)$ \\
\hline$>11$ & $72(69.0)$ & $187(90.3)$ & $276(89.0)$ \\
\hline Total & $103(100)$ & $207(100)$ & $310(100)$ \\
\hline Mean & 18.65 & 24.53 & 14.95 \\
\hline \multirow[t]{2}{*}{ t-value } & $-32.30 *(12.13)$ & & \\
\hline & \multicolumn{2}{|c|}{ Rice Farming Experience(yr) } & \\
\hline$\leq 3$ & $9(8.7)$ & $07(3.3)$ & $16(5.2)$ \\
\hline $4-7$ & $22(21.4)$ & $32(15.5)$ & $54(17.4)$ \\
\hline $8-11$ & $23(22.3)$ & $56(27.1)$ & $79(25.5)$ \\
\hline$>11$ & $49(47.6)$ & $112(54.1)$ & $161(51.9)$ \\
\hline Total & $103(100)$ & $207(100)$ & $310(100)$ \\
\hline Mean & 13.63 & 15.61 & 14.95 \\
\hline \multirow[t]{2}{*}{ t-value } & $-25.78^{*}(9.75)$ & & \\
\hline & \multicolumn{2}{|c|}{ Number of family members actively involved in rice farming } & \\
\hline$\leq 3$ & $44(42.7)$ & $119(57.5)$ & $163(52.6)$ \\
\hline $4-7$ & $39(37.9)$ & $71(34.3)$ & $110(35.4)$ \\
\hline $8-11$ & $218(17.5)$ & $12(5.8)$ & $30(9.7)$ \\
\hline$>11$ & $2(1.9)$ & $5(2.4)$ & $7(2.3)$ \\
\hline Total & $103(100)$ & $207(100)$ & $310(100)$ \\
\hline Mean & 4.23 & 3.94 & 4.23 \\
\hline t-value & $-23.62 *(2.90)$ & & \\
\hline
\end{tabular}


Table 3. Respondents Distribution by Area of land cultivated for rice, membership of cooperative group, access to credit and access to extension agents

\begin{tabular}{|c|c|c|c|}
\hline Land area (ha) & Ekiti & Ogun & Pooled \\
\hline$\leq 1$ & $43(41.7)$ & $93(44.9)$ & $136(43.9)$ \\
\hline $1.1-2.0$ & $28(27.2)$ & $72(34.8)$ & $100(32.3)$ \\
\hline $2.1-3.0$ & $17(16.5)$ & $29(14.0)$ & $46(14.8)$ \\
\hline $3.1-4.0$ & $8(7.8)$ & $4(1.9)$ & $12(3.9)$ \\
\hline $4.1-5.0$ & $6(5.8)$ & $8(3.9)$ & $14(4.5)$ \\
\hline$>5$ & $1(1.0)$ & $1(0.5)$ & $2(0.6)$ \\
\hline Total & $103(100)$ & $207(100)$ & $310(100)$ \\
\hline Mean & 1.99 & 1.59 & 1.72 \\
\hline \multirow[t]{2}{*}{ t-value } & $-20.06 *(0.07)$ & & \\
\hline & \multicolumn{2}{|c|}{ Membership of cooperative group } & \\
\hline Member & $80(77.7)$ & $141(68.1)$ & $221(71.3)$ \\
\hline Not member & $23(22.3)$ & $66(31.9)$ & $89(28.7)$ \\
\hline Total & $103(100.0)$ & $207(100.0)$ & $310(100.0)$ \\
\hline \multirow[t]{2}{*}{ Mode } & member & Member & Member \\
\hline & \multicolumn{2}{|l|}{ Access to credit } & \\
\hline Access to credit & $37(35.9)$ & $23(11.1)$ & $60(19.4)$ \\
\hline No Access credit & $66(64.1)$ & $184(88.9)$ & $250(80.6)$ \\
\hline Total & $103(100)$ & $207(100)$ & $310(100)$ \\
\hline \multirow[t]{2}{*}{ Mode } & No access & No access & No access \\
\hline & \multicolumn{2}{|c|}{ Access to extension agents } & \\
\hline Access to extension & $8(7.8)$ & $37(17.9)$ & $45(14.5)$ \\
\hline No access & $95(92.2)$ & $170(82.1)$ & $266(85.5)$ \\
\hline Total & $103(100)$ & $207(100)$ & $310(310)$ \\
\hline Mode & No access & No access & No access \\
\hline
\end{tabular}

Figures in parentheses are percentages except for t-value, ${ }^{*}$ significant levels at $10 \%$

Source: Estimates from field survey, 2010

Table 4. Groups Activities and Changes that Encourage Participation

\begin{tabular}{|l|l|l|l|}
\hline Activities & Not important & Important & Very important \\
\hline Change of leaders and leadership styles & $164(53)$ & $101(32)$ & $45(15)$ \\
\hline Increase in off-farm activities & $52(16.8)$ & $130(41.9)$ & $128(41.3)$ \\
\hline Facilitating access to credit & $18(5.8)$ & $68(21.9)$ & $224(72)$ \\
\hline Facilitating access to farm inputs & $27(8.7)$ & $74(23.9)$ & $209(67.4)$ \\
\hline Gender specific groups & $219(70.6)$ & $73(23.5)$ & $18(5.8)$ \\
\hline Access to land clearing facility & $95(30.6)$ & $84(27.1)$ & $131(42.3)$ \\
\hline Access to tractor services & $208(67.1)$ & $5599(17.7)$ & $47(15.2)$ \\
\hline Access to extension services & $214(69)$ & $77(24.8)$ & $19(6.1)$ \\
\hline Access to processing mill & $26(8.4)$ & $94(30.3)$ & $190(61.3)$ \\
\hline Access to better markets & $17(5.5)$ & $32(10.3)$ & $261(84.2)$ \\
\hline
\end{tabular}

Note: Values in parenthesis are percentages.

Source: Authors calculation from data from field survey 2010 
Table 5. Costs- Return Structure for the Average Rice Farmers in a Production Season

\begin{tabular}{|l|l|l|}
\hline Variables & Cooperative member & Non-Cooperative \\
\hline Average land size(ha) & 1.72 & 1.64 \\
\hline Average yield (tonnes / ha) & 1.43 & 1.41 \\
\hline Total revenue (naira) & 394,671 & 361,552 \\
\hline Cost of land preparation (Naira) & $24,822(8.15)$ & $25,625(9.54)$ \\
\hline Cost of seeds and planting(Naira) & $23,988(7.88)$ & $24,892(9.27)$ \\
\hline Cost of weeding labour (Naira) & $14,627(4.80)$ & $23,827(8.87)$ \\
\hline Cost of fertilizer and application(Naira) & $78,627(25.83)$ & $41,820(15.57)$ \\
\hline Cost of pesticides and application(Naira) & $45,928(15.09)$ & $15,827(5.89)$ \\
\hline Cost of bird scaring & $51,827(17.02)$ & $66,828(24.88)$ \\
\hline Harvesting cost(Naira) & $23,809(7.82)$ & $26,918(10.02)$ \\
\hline Milling and transport cost (Naira) & $40,821(13.41)$ & $42,829(15.95)$ \\
\hline Total variable cost (naira) & $304,449(100)$ & $268,566(100)$ \\
\hline Gross margin (naira) & $\mathbf{9 0 , 2 2 2}$ & $\mathbf{9 2 , 9 8 6}$ \\
\hline
\end{tabular}

Source: Authors calculation from 2010 field survey data

Values in parenthesis are percentages of total variable cost

Table 6. Results of Probit model on the effects of group membership on access to agricultural inputs and rice production (Pooled data)

\begin{tabular}{|c|c|c|c|}
\hline Variables & Coefficient & Prob. & Marginal effect \\
\hline Location (State) & $-0.5065(0.2130)^{* *}$ & 0.017 & -0.1436 \\
\hline Gender & $-0.3733(0.2907)$ & 0.199 & -0.1018 \\
\hline Marital status & $-0.2924(0.2781)$ & 0.327 & -0.0838 \\
\hline Age & $-0.0091(0.0136)$ & 0.9506 & -0.00276 \\
\hline Education & $0.1166(0.2219)$ & 0.599 & 0.03631 \\
\hline Household size & $-0.0875(0.0378)^{* *}$ & 0.021 & -0.0267 \\
\hline $\begin{array}{l}\text { No of family members in rice } \\
\text { production }\end{array}$ & $0.05214(0.0344)$ & 0.130 & 0.01589 \\
\hline General farming experience & $0.01644(0.01302)$ & 0.207 & 0.005012 \\
\hline Rice farming experience & $-0.0113(0.0131)$ & 0.386 & -0.003456 \\
\hline No of farm locations & $0.7178(0.2446)^{*}$ & 0.003 & 0.21878 \\
\hline Area of land cultivated & $-0.0506(0.0794)$ & 0.523 & -0.01544 \\
\hline Access to fertilizer & $-0.2433(0.1939)$ & 0.210 & -0.07630 \\
\hline Access to herbicide & $-1.4462(0.2196)^{*}$ & 0.000 & -0.4843 \\
\hline Access to credit & $0.3586(0.2611)$ & 0.170 & 0.09974 \\
\hline Access to extension agent & $-0.61055(0.2592)^{* *}$ & 0.019 & -0.2109 \\
\hline Quantity of rice produced & $0.000216(0.0006)$ & 0.362 & 0.0000658 \\
\hline Constant & $2.4148(0.8158)$ & 0.003 & - \\
\hline Loglikelihood ratio $\mathrm{Chi}^{2}$ & 94.35 & & \\
\hline Prob $\leq \mathrm{Chi}^{2}$ & 0.000 & & \\
\hline Pseudo $\mathrm{R}^{2}$ & 0.2589 & & \\
\hline Loglikelihood & -135.0498 & & \\
\hline Dependent variable $(\operatorname{Pr}(\mathrm{y})$ predict & 0.7634 & & \\
\hline
\end{tabular}

Note: $* \mathrm{P}<0.01,{ }^{*} * \mathrm{P}<0.05$ value in parenthesis are standard errors

Source: Authors calculation using data from field survey 2010 
Table 7. Results of Probit model on the effects of group membership on access to agricultural inputs and rice production in Ekiti State

\begin{tabular}{|l|l|l|l|}
\hline Variables & Coefficient & Prob. & Marginal effect \\
\hline Gender & $2.1484(0.7408)^{*}$ & 0.004 & 0.6841 \\
\hline Marital status & $0.7585(1.2040)$ & 0.529 & 0.2049 \\
\hline Age & $-0.0148(0.0292)$ & 0.611 & -0.002763 \\
\hline Education & $-0.1344(0.5144)$ & 0.794 & -0.02362 \\
\hline Household size & $-0.1053(0.01021)$ & 0.302 & -0.01965 \\
\hline No of family members in rice production & $0.05715(0.0893)$ & 0.522 & 0.010667 \\
\hline General farming experience & $0.02416(0.0284)$ & 0.399 & 0.00451 \\
\hline Rice farming experience & $-0.005716(0.02962)$ & 0.847 & -0.001066 \\
\hline No of farm locations & $0.50093(0.34047)$ & 0.141 & 0.09349 \\
\hline Area of land cultivated & $0.16801(0.1845)$ & 0.363 & 0.03136 \\
\hline Access to fertilizer & $-0.2866(0.4301)$ & 0.505 & -0.52104 \\
\hline Access to herbicide & $2.1657(0.5608)^{*}$ & 0.000 & 0.52104 \\
\hline Access to credit & $-0.2841(0.4628)$ & 0.539 & -0.05929 \\
\hline Access to extension agent & $-0.1575(0.6446)$ & 0.807 & -0.03154 \\
\hline Quantity of rice produced & $0.000694(0.0001172)$ & 0.554 & 0.00015 \\
\hline Constant & $-0.4485(2.0133)$ & 0.823 & - \\
\hline Loglikelihood ratio Chi ${ }^{2}$ & 38.09 & & \\
\hline Prob Chi ${ }^{2}$ & 0.0009 & & \\
\hline Pseudo ${ }^{2}$ & 0.3549 & & \\
\hline Loglikelihood & -34.6212 & & \\
\hline Dependent variable (Pr(y) predict & 0.8911 & & \\
\hline Not $* 0.01, * 0.05$ val & & \\
\hline
\end{tabular}

Note: $* \mathrm{P}<0.01, * * \mathrm{P}<0.05$ value in parenthesis are standard errors

Source: Authors calculation using data from field survey 2010

Table 8. Probit regression model on the effects of group membership on access to agricultural inputs and rice production in Ogun State

\begin{tabular}{|c|c|c|c|}
\hline Variables & Coefficient & Prob. & Marginal effect \\
\hline Gender & $-07480(03402)^{* *}$ & 0.028 & -0.1975 \\
\hline Marital status & $0.11967(0.5528)$ & 0.829 & 0.0401 \\
\hline Age & $-0.0148(0.0179)$ & 0.407 & -0.0004812 \\
\hline Education & $0.25598(0.2624)$ & 0.329 & 0.08564 \\
\hline Household size & $-0.0994(0.0462)^{* *}$ & 0.032 & -0.0322 \\
\hline No of family members in rice production & $0.09005(0.0421)^{* *}$ & 0.032 & 0.02921 \\
\hline General farming experience & $0.0249(0.01697)$ & 0.142 & 0.008077 \\
\hline Rice farming experience & $-0.01743(0.01726)$ & 0.313 & -0.00565 \\
\hline No of farm locations & $0.9491(0.4130)^{* *}$ & 0.022 & 0.3079 \\
\hline Area of land cultivated & $-0.1779(0.1098)$ & 0.105 & -0.05772 \\
\hline Access to fertilizer & $-0.2891(0.2377)$ & 0.224 & -0.09609 \\
\hline Access to herbicide & $1.4220(0.2808)^{*}$ & 0.000 & 0.4995 \\
\hline Access to credit & $0.7923(0.3475)^{* *}$ & 0.023 & 0.2112 \\
\hline Access to extension agent & $-0.5740(0.3031)^{* * *}$ & 0.058 & -0.2055 \\
\hline Quantity of rice produced & $0.000261(0.0000757)^{*}$ & 0.001 & 0.0000848 \\
\hline Constant & $1.8168(0.9905)$ & 0.067 & - \\
\hline Loglikelihood ratio $\mathrm{Chi}^{2}$ & 76.85 & & \\
\hline Prob $\mathrm{Chi}^{2}$ & 0.000 & & \\
\hline Pseudo $\mathrm{R}^{2}$ & 0.2992 & & \\
\hline Loglikelihood & -90.00155 & & \\
\hline Dependent variable $(\operatorname{Pr}(\mathrm{y})$ predict & 0.7399 & & \\
\hline
\end{tabular}

Note: ${ }^{*} \mathrm{P}<0.01,{ }^{* *} \mathrm{P}<0.05,{ }^{* * *} \mathrm{P}<0.1$, value in parenthesis are standard errors

Source: Data Analysis (2010) 
Table 9. Test of significant differences in rice production variables between cooperative and non- cooperative members

\begin{tabular}{|l|l|l|l|}
\hline & \multicolumn{2}{|c|}{ Mean values } & \\
\hline Production variables & $\begin{array}{l}\text { Cooperative } \\
\text { members }\end{array}$ & Non-members & t-value \\
\hline Land area cultivated (ha) & 1.72 & 1.64 & 0.33 \\
\hline Number of rice harvest per year & 1.01 & 1.04 & 0.76 \\
\hline Yield (tonnes/ha) & 1.43 & 1.41 & 1.055 \\
\hline Gross Margin & 90,222 & 92,986 & 1.065 \\
\hline
\end{tabular}

Authors' calculation from 2010 field survey data

Table 10. Factors Influencing Group Formation and Development in the Study Areas

\begin{tabular}{|l|c|c|c|c|c|c|}
\hline \multirow{2}{*}{ Variables } & \multicolumn{2}{|c|}{ Ekiti State } & \multicolumn{2}{|c|}{ Ogun State } & \multicolumn{2}{|c|}{ Total } \\
\cline { 2 - 7 } & Freq & \% & Freq & \% & Freq & $\%$ \\
\hline Group strength & & & & & & \\
Good leadership/management & 11 & 10.7 & 48 & 23.2 & 59 & 19.0 \\
Access to loan & 33 & 32.0 & 81 & 39.1 & 114 & 36.8 \\
Regular meeting schedule & 21 & 20.4 & 47 & 22.7 & 68 & 21.9 \\
Membership cooperation & 15 & 14.7 & 57 & 27.5 & 72 & 23.2 \\
Team work & 13 & 12.6 & 47 & 22.7 & 60 & 19.4 \\
Proportionate distribution of items/credit & 19 & 18.4 & 42 & 20.2 & 61 & 19.7 \\
Facilitation of loan acquisition & 27 & 26.2 & 69 & 33.3 & 96 & 31.0 \\
Common interest and goals & 11 & 10.7 & 51 & 24.6 & 62 & 20.0 \\
\hline Threat to group existence & & & & & & \\
Poor leadership style & 53 & 51.5 & 87 & 42.0 & 140 & 45.2 \\
Poor membership contribution & 65 & 63.1 & 93 & 44.9 & 158 & 76.3 \\
Lack of membership commitment & 37 & 35.9 & 64 & 30.9 & 101 & 48.8 \\
Selfishness of members & 28 & 27.2 & 71 & 34.3 & 99 & 47.8 \\
Lack of membership cooperation & 33 & 32.0 & 105 & 50.7 & 138 & 66.7 \\
Disproportionate distribution of items & 28 & 27.2 & 86 & 41.5 & 114 & 55.1 \\
Inability to access loan & 71 & 68.9 & 111 & 53.6 & 118 & 57.0 \\
\hline
\end{tabular}

